\title{
Thoughts on the Organization and Implementation of the Curriculum Content of the Professional Introduction in Universities and Colleges
}

\author{
Fuwei \\ College of electrical and information engineering \\ Beihua University \\ Jilin City, China \\ 6412978@qq.com
}

\author{
Baijing \\ College of electrical and information engineering \\ Beihua University \\ Jilin City, China
}

\begin{abstract}
Establishing the professional introduction course in colleges and universities is to make students understand the professional characteristics and the direction of development. However many colleges and universities have already deviated from the purpose of the establishment of the professional introduction this paper analyzed the reasons for this phenomenon and took Beihua university institute of electrical and information engineering professional introduction of automation specially as an example .we have probed and practical in the organization of curriculum content and teaching methods, meanwhile we have achieved good results. So, provide a reference for other colleges and universities of professional introduction course.
\end{abstract}

Keywords-professional Introduction, career planning, higher education, Specialty characteristics

\section{INTRODUCTION}

For the purpose of higher education is to stimulate students' ability for studying and passion extremely in subjects during educational process, to make them to probe the content which has to do with their subjects consciously. Most of them don't know about what is the subject which they will learn in the follow four years at all, when they received the offer from colleges. So they don't know if they will like the subject or not even don't know what kind of jobs they can find when they finished subjects from their college. So this important to provide the professional introduction course with them as soon as the new students enter the college, if the students don't like the subject they will have other chance to choose, if the students like the subject they can know how many directions on the subject, so that they can choose which they are interested in .The professional introduction course is opened to make the line and direction of lasting course clear. At present most college just begin to know the professional introduction course and teaching study. So they haven't agreed on the content and teaching methods for the course .It's summarize by teaching in college for many years, the author think the content for professional introduction course is to tell the students about 5questions :first, what is subject and it's value, second how many researching directions does the subject contain, third in this subject how many courses the students will learning, and the relationship between the coursers, fourth during the four years the students will study in college, how to spend their time in college. They maybe learn the skills which support they living in society, they maybe waste their time for game .fifth tell the students what kinds of abilities they should hold before they graduated from college. So the professional introduction course is very important for these students who don't know the subject study. When they enter the college during the professional introduction course they know what they will study, how to study in college, choose a direction which they are interested in .A lot of college have organized the professional introduction course in the education at scheme Most students don't know what is the subject they study, and don't know how to study in the college, in this course they have told the history of subject, or some new theories in subject, or some new research for direction. The author think there are many problems need to solve such as how to organize the content for this course, how to easy understand for the students easily who have never mentioned the subject before.

\section{THE SHOCK POINT OF THE DEVELOPMENT OF PROFESSIONAL INTRODUCTION COURSE AND ITS REASONS}

\section{A. Some colleges ignore the professional introduction course can play an important role in the teaching process.}

In china, traditional conception is that the institution of higher learning is more inclined to arrange exact theoretical teaching content, or pay more attention to new technologies, methods and crafts. At first the professional introduction course wasn't supported widely. The teacher who teaches the professional introduction course often tell the freshman what is newest technologies or the newest theories to show their knowledge instead introduction subject.The freshman just enter the college who never contacts the content with the subject. It's hard to understand the professional content, even though they finish the professional introduction. They will still feel confused on this occasion most students study hard so as to pass the exam once they passed the exam.

Usually the introduction course is often arranged in the first term when the students just enter college. If the professional introduction can play it is own role, the freshman 
can find their happiness in study. And most students can understand the relationship among courses, and then choose a direction which they like.

\section{B. The shortage of teachers, and the teachers don't spend their time in this course}

Now the colleges or the universities will assess the teacher who is working for them at the end of year. They will counter the hours for teaching, the number and the level of scientific research, the amount of funds which come from the government or the company for scientific research. So many teachers put their energy into these items, and want to get a good assess. If the teacher spend their time on the course such as professional introduction they can't get a good assess, and they will lost many choices to get better job. But the course such as professional introduction need an excellent teacher, who has the ability to teach the students understand the complex theories in easy way which often exist in their life. The teacher understands the relationship among the courses in subject, have abundant experiences in teaching, pay attention to the teaching methods. Most of teachers maybe teach several courses for long time, they will pay attention to the relationship between concepts, lack of the relationship between the courses. The over all framework of knowledge will be divided into strips. So it's more difficult to find an excellent teacher to organize the course is not easy work.

\section{Lack of the proper book for freshman.}

In the educational process, many students can't get the proper book which is suitable for the professional introduction course. So many colleges or universities have same the subject but focus on different directions. If the teacher can't organize the contents from the history of subjects, show the special subject characters to the students, he can't teaches the student the real meaning of the professional introduction course. And the professional introduction course will became the history course or the newest technology course, can't play the real role of initiation in subject education.

There are many problems in professional introduction course but the above three problems are the main problems. If we want to improve the effect of this course, the three problems must be solved. In the educational process, the teacher and the students play different roles, assess the effect of course, need to assess if the students understand what the teacher said, and main idea of the course. If we can get to have the students interests in the course, the teacher organize the contents and the way of teaching must know what the students' interests in. Follow the students characters to arrange the teach action.

\section{FOCUS ON LEARNING CHARACTERISTICS AND KEYS WHICH THE STUDENTS IN COLLEGES AND UNIVERSITIES}

In college educated process can't lack of students attention to, so organizing the content and teaching methods must follow the ability of students. Meanwhile the freshman, who just enter the college will charge that improve their knowledge with the development of social suite from time to time.
For the freshman who has just entered college, everything making them surprised in usually. Such as dormitory the like tow month time which is spent by them freely and they won't be charged by their head teacher ;won't live with their parents anymore. The life in college just is amusement are heaven .They are too young to know the things, these wrong opinion will be corrected during teaching activities in higher education.

The freshmen in college pay more attention fourth problems: 1) what is the value of subject .2) what they should learn in further. 3) How to study in college? 4) what kind of job they can find after graduating?

After college entrance examination, many students should choose a subject for their study in college. But most students and their parents don't understand what the subject is. They often listen to others views about subject of college, The parents hardly consider the children's interests to choose subjects. So some students enter the college find that the subject they don't like, if they are lucky dogs they have a chance to change their subjects, if they unfortunately can't change their subject the students won't be interested of studying, they maybe lose themselves in the PC game. So you can find the students who study well in Senior high school, but can't study well in college.

Learning is major job for freshman, the courses have relationship between each others, some courses are supported, we called courses group. These courses group can be divided into such as basic course, professional course, profession practicing course and so on. Different course group has different ways to study .The students can choose which course group they have interests in.

In college the contents for course need students to remember is becoming less than that in senior high school. Most of the contents need the students understand, and the amount of knowledge which mentioned in class is more than that in senior high school. The students have a lot of time to study by themselves; the way to study is so different from that in senior high school. So the freshman wants to get better grades who must find a new way to study in college.

Just enter the college, the students will meet a lot of difficulties and a lot of problems, these problems or difficulties can be solved by finding the good way in the professional introduction course. So choosing a proper time to arrange professional introduction course is very important, this course can help the student as soon as they find a new way to study other course, and find a new way to live in college.

\section{EXPLORATION AND PRACTICE FOR PROFESSIONAL INTRODUCTION COURSE}

On the basis of the analysis of the problems in professional introduction course, we try our best to find a new way to solve the problem. Our purpose is that the professional introduction course plays itself own role in education, become the list for the following courses. So the students clear the relationship between each course. 
In this teaching practice, the automation subject of Electrical Information Engineering College of Beihua University is selected as an example. According to the characteristics and history of Automation Subject in Beihua University Institute of electrical and Information Engineering, the content of professional introduction course is written by the professional teachers who have many years teaching experiences in this subject. The mind of writing contents is to answer the questions which the students are most interested in, such as what is the subject, what are the researching directions, and tell students if they want to research the direction what skills are needed, what kind of jobs they can find when they graduated from college. In contents stress the relationship between basic courses and professional course. The teaching methods stress translate the theories into oral language .Let the students understand what courses they will learn in future, and each course how to study, why they will study these courses. Most students are interested in the subject when they finished this course, have achieved their goals. Facts prove the contents written are very useful.

Except for good contents, we also need good teachers. So we choose the teacher who has taught five different courses, clearly the relationships between the courses of subject. Have the experience for Electronic competition. The teacher during the educational process can tell the students how to do for their dreams such as take part in the entrance exams for postgraduate schools, and the companies' employee skills requirements. So the students know what they should to do in coming years. In the teaching method we choose the way to ask and answer mode, students can find date in library or the internet. In this way the students have to think about the question by themselves, it's better than the teaching method which the teachers tell the students to listen .If the students have any questions about the contents, they can write these questions on the paper then send these to their teacher by email. No matter what, teachers will give the answers as soon as possible. In this way, the students start to think about things by themselves, and can give the answer belong to them.

Through the students find date in library or the internet by themselves, the freshman can find a new way for college study. And it's better for them to study in the college. Because of the professional introduction course only taught in the first term, following the time, students will usually forget the method to study in college and the relationship among courses. So we have class tutor who is responsible for students to study, he can repeat the relationship among courses and the importance for the course at the beginning of the new term. Reduce the confusion in studying for students.

Table 1 gives the name of each section of the professional introduction course.
TABLE I. THE NAME OF EACH SECTION OF THE PROFESSIONAL INTRODUCTION COURSE

\begin{tabular}{|c|c|c|}
\hline chapter & content & \\
\hline 1 & $\begin{array}{l}\text { Content and significance of Higher } \\
\text { Education }\end{array}$ & \multirow{4}{*}{$\begin{array}{l}\text { Let the students } \\
\text { understand why they } \\
\text { should receive the } \\
\text { higher education, } \\
\text { their subject } \\
\text { characteristics }\end{array}$} \\
\hline 1.1 & The demand for higher education & \\
\hline 1.2 & $\begin{array}{c}\text { Contents and characteristics of } \\
\text { Higher Education }\end{array}$ & \\
\hline 1.3 & $\begin{array}{l}\text { Development status of automation } \\
\text { at home and abroad }\end{array}$ & \\
\hline 2 & Character of subject & \multirow{4}{*}{$\begin{array}{l}\text { Let students } \\
\text { understand the } \\
\text { relationship among } \\
\text { university courses } \\
\text { and the subject } \\
\text { characteristics }\end{array}$} \\
\hline 2.1 & Main research direction and value & \\
\hline 2.2 & Relationship of course group & \\
\hline 2.3 & $\begin{array}{l}\text { The character for automation and } \\
\text { the ability for job demanded }\end{array}$ & \\
\hline 3 & Professional teaching arrangement & \multirow{4}{*}{$\begin{array}{l}\text { Tell the student why } \\
\text { they need experience } \\
\text { practice; and what } \\
\text { experiment the } \\
\text { college can be } \\
\text { offered }\end{array}$} \\
\hline 3.1 & $\begin{array}{l}\text { Skill requirement of professional } \\
\text { talents }\end{array}$ & \\
\hline 3.2 & $\begin{array}{l}\text { Professional teaching plan and } \\
\text { credit arrangement }\end{array}$ & \\
\hline 3.3 & $\begin{array}{l}\text { Professional teaching resources and } \\
\text { practice arrangement }\end{array}$ & \\
\hline 4 & How to study in University & \multirow{5}{*}{$\begin{array}{l}\text { Tell the students } \\
\text { how to study in } \\
\text { college, the } \\
\text { character of college } \\
\text { study }\end{array}$} \\
\hline 4.1 & $\begin{array}{l}\text { The way and means of obtaining } \\
\text { knowledge in the university }\end{array}$ & \\
\hline 4.2 & $\begin{array}{l}\text { The practice base and the game can } \\
\text { improve practical ability }\end{array}$ & \\
\hline 4.3 & $\begin{array}{l}\text { The acquisition and utilization of } \\
\text { scientific and technological } \\
\text { documents, and how to write the } \\
\text { paper writing }\end{array}$ & \\
\hline 4.4 & $\begin{array}{l}\text { Application and improvement of } \\
\text { College Students' science and } \\
\text { technology projects }\end{array}$ & \\
\hline 5 & $\begin{array}{l}\text { Employment and future career } \\
\text { development trends }\end{array}$ & \multirow{3}{*}{$\begin{array}{l}\text { The direction of } \\
\text { future employment, } \\
\text { the enterprise for the } \\
\text { employee's ability } \\
\text { and quality } \\
\text { requirements }\end{array}$} \\
\hline 5.1 & $\begin{array}{l}\text { the reason of further study such as } \\
\text { Preparing for postgraduate entrance } \\
\text { examination }\end{array}$ & \\
\hline 5.2 & $\begin{array}{l}\text { Requirements for professional } \\
\text { competence in the workplace }\end{array}$ & \\
\hline
\end{tabular}

\section{CONClusion ANd Prospect}

Through testing twice the new professional introduction course, compared to the students who receive the old professional introduction course. The students who receive new professional introduction course have more interested in studying. They know what they are must study, and how to study. They are eager to study new knowledge in order to find a better job when they graduated from school. In addition, through the introduction of professional courses teaching, students have cleared the general process of scientific research [6], improve the students' interests in subject. Through this course students establish a concept that technology can solve the real needs. Many students take an advice part in the various competitions, and make an example for other students in learning with the passion.

Summary of the current results, we used excellent teacher to teach this course, and many teacher together writing suitable book which base on our college automation subject. It's the key of the success of this course we should affirm and 
support what the teachers do, certainly there are still too much work for us to explore in future we believe other brother colleges will find better methods and contents for the professional introduction course.

\section{REFERENCES}

[1] Cong Juan. "Exploration and practice of mechanical professional introduction course" [J] Journal of Liaoning Institute of Science and Technology 2016, 18 (1): 54-55 (In Chinese)

[2] Xie Wei, the dragon spring, China Manyu. "Introduction of professional courses in Colleges and universities teaching practice and thinking of "2016 [J] Teaching education Forum, 13:135-137(In Chinese)
[3] Guo Yuxing. "The opening of an introduction to the freshman major in Colleges and universities" [J]. science and education department, 2013, (7): 40-41 (In Chinese)

[4] Yang Xiaodong, Cui Yaxin, Liu Guifu, "an introduction to the introduction of professional courses in Colleges and universities" [J] Heilongjiang higher education research 2010, 7:147-149(In Chinese)

[5] Liu Guangming, Yu Fei, Zhou ya, Zhao Qing. "Explore set up professional introduction course of lower grade undergraduate course" [J] Higher Education Forum 2007, 2:37-39 (In Chinese)

[6] Du Wenfeng. "Introduction to the teaching of the course of the introduction to the physics of the earth" $[\mathrm{J}]$ the teaching practice of Education Forum 2015, 9:131-132 (In Chinese) 